\title{
Dynamics of Human-Water Interactions in the Kilombero Valley, Tanzania: Insights from Farmers' Aspirations and Decisions in an Uncertain Environment
}

\author{
Britta Höllermann ${ }^{1}$ (D) Kristian Näschen ${ }^{1}$ (D) - Naswiru Tibanyendela ${ }^{2,3}$. \\ Julius Kwesiga ${ }^{2} \cdot$ Mariele Evers $^{1}$
}

Accepted: 13 March 2021 / Published online: 7 April 2021

(C) The Author(s) 2021

\begin{abstract}
The Kilombero Valley, one of East Africa's largest seasonal wetlands, is a highpotential agricultural development corridor area in Tanzania. This seasonally flooded wetland is mainly used by smallholder farmers who cultivate during the rainy season, although there are some community-based irrigation systems that reduce hydro-climatic risks. In this study, we aim to understand how farmers' aspirations and visions about the future are related to the current agricultural practices and human-water interaction. We specifically investigate the differences between farmers from rainfed and irrigated agriculture by using focus group discussions. Analysis of the in-depth interviews highlights how farmers' actions both shape and respond to this highly dynamic and uncertain environment. Furthermore, we identify a close link, driven by the farmers' level of agency, between aspirations and expected agroeconomic development. The heterogeneity of farmers' agency and hence their ability to cope with change is not only based on the socioeconomic status but also on their perception of the physical environment. We thus recommend that attention is also paid to the capacity for coping with environmental challenges that influences the level of farmers' aspiration.
\end{abstract}

Keywords Hydro-climatic risk $\cdot$ Smallholder farmers $\cdot$ Decision-making under uncertainty $\cdot$ Focus group discussions · Aspiration gap · Agro-economic development

\section{Résumé}

La vallée de Kilombero, l'une des plus vastes zones humides saisonnières d'Afrique de l'Est, est un corridor de développement agricole à fort potentiel en Tanzanie. Cette zone humide, innondée de façon saisonnière, est principalement utilisée par les petits exploitants qui la cultivent pendant la saison des pluies, bien qu'il

Britta Höllermann

bhoellermann@uni-bonn.de

Extended author information available on the last page of the article

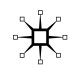


existe certains systèmes d'irrigation à base communautaire qui réduisent les risques hydro-climatiques. Dans cette étude, nous cherchons à comprendre comment les aspirations et visions de l'avenir des agriculteurs sont liées aux pratiques agricoles actuelles et à l'interaction entre les hommes et l'eau. Nous étudions plus spécifiquement les différences entre les agriculteurs de l'agriculture pluviale et ceux de l'agriculture irriguée en utilisant des discussions de groupe. L'analyse des entretiens approfondis met en évidence la manière dont les actions des agriculteurs façonnent et s'adaptent à cet environnement hautement dynamique et incertain. En outre, nous identifions un lien étroit, qui dépend du pouvoir d'agir des agriculteurs, entre les aspirations et le développement agro-économique attendu. L'hétérogénéité du pouvoir d'agir des agriculteurs et, par là, leur capacité à faire face au changement ne prennent pas seulement racine dans leur statut socio-économique mais aussi dans leur perception de l'environnement physique. Nous recommandons donc d'accorder également de l'attention à la capacité de faire face aux défis environnementaux qui influencent le niveau d'aspiration des agriculteurs.

\section{Introduction}

Africa is still considered to have vast land reserves for conversion into arable land, particularly from the Lake Tana basin in Ethiopia and in the East to the Limpopo River basin in the South (Finlayson et al. 2018). Large-scale land use intensification to meet growing food demand is at the core of many development corridors in the region. One of the priority areas for agricultural intensification within the Southern Agricultural Growth Corridor of Tanzania (SAGCOT) is the Kilombero Valley. The Kilombero Valley is a high-potential area due to its fertile soils and prolonged water availability (Milder et al. 2013; Tanzania 2013; Nindi et al. 2014; Sulle 2020). It is a very dynamic environment (Leemhuis et al. 2016) affected by increasing variability in the onset and intensity of the rainy season (Näschen et al. 2019b). Agricultural production needs not only to cope with, but also adapt to the changing availability of water during the course of the year (Gabiri et al. 2018; Kwesiga et al. 2019; Kwesiga et al. 2020). Agricultural development has been prioritized by Tanzania's development vision formulated in the Kilimo Kwanza or Agriculture First initiative and set to be achieved through the more recent SAGCOT initiative. SAGCOT envisions sustainable agricultural intensification with irrigation schemes for, e.g., rice cultivation on a large scale (Tanzania 2013). In contrast to this national vision stands a majority of smallholder farmers who practice more extensive, rainfed agriculture in the Kilombero Valley. While the national vision of agricultural development aspires to increase food production through large-scale farming and aims to attract further-and also international-financial investments and development (Sulle 2020), the aspirations of the farmers are more diverse. Sulle (2020) points out that the national vision(s) find reshaping through local agency. However, to understand - in this case_-farmers' decision-making — it is important to focus on their aspirations (Rao et al. 2020). Aspirations are understood as motivators to aim for a better livelihood (Bernard and Taffesse 2014) driven by the hope to achieve something specific (Kremer et al. 2019). In contrast to expectations, the aspired ambitions must not necessarily be realistic or internalize constraints. Aspirations rather describe the 
ambition to achieve something even if these are outside the range of outcomes determined by the personal situation (La Ferrara 2019). Hence, aspirations present "an orientation towards a desired future" (Huijsmans et al. 2020) and are closely linked to decision-making and livelihood strategies (Dorward et al. 2009). They affect the current practices and decisions by aiming at closing the gap between the current situation and the aspired condition (Rao et al. 2020). Kosec and Mo (2017) find that the higher the aspirations, the higher is the willingness to invest in this future. However, the capacity to aspire is lower among the poor due to a lack of opportunity (Appadurai 2004). Thus, the extent of individual action is confined by a combination of agency and structural constraint (Cleaver 2002). As these actions also emerge through social action, the extent of the individual action is assumed to be locally clustered and unevenly distributed (Appadurai 2004; Ray 2006). Furthermore, the influence of relevant peers, e.g., farmer's colleagues, who are in a similar position, is powerful as it frames and confines the perceived possibilities which Ray (2006) describes as the window of aspiration. Why farmers prefer some choices over others to, e.g., adapt to the climatic conditions, needs a good understanding of their aspirations (Rao et al. 2020). Hence, understanding farmers' aspirations and the factors influencing these aspirations is important for effectively supporting development in agriculture (Mausch et al. 2018; Verkaart et al. 2018; Kremer et al. 2019).

Our conceptual framework builds on this close relationship between agency and aspiration and adds to this duality the impact of the physical environment, e.g., climate variability, as an important third influence on farmers' decision-making and agricultural practices. We hypothesize that the interplay of agency, aspirations, and physical environment shapes farmers' decisions and that there is a need to include environmental factors and farmers' interaction with the physical environment to fully understand the heterogeneity of farmers practices. For this, we survey the current agricultural practices and decision-making strategies of smallholder farmers with and without access to irrigation and analyze how, in addition to the farmers' agency and aspirations, different resource bases influence agricultural decisions. Within the context of a highly dynamic and uncertain environment, we especially look at how these aspirations not only relate to broader socioeconomic status, but also to individual or group-based environmental perceptions and coping capacities. Thus, we believe that including the impact of the physical environment as a third influence will add another important driver to understand the unevenly distributed levels of aspiration.

Our research is part of the collaborative research center on "Future Rural Africa: Future-making and social-ecological transformation" (www.crc228.de) which aims at examining processes and practices that reflect visions of the future, influence contemporary decisions, and thereby prepare the ground for processes that shape future conditions. 


\section{Environmental Setting of the Kilombero Valley}

\section{Study Area}

The Kilombero Valley is in the Morogoro region in South Central Tanzania (Fig. 1) bordered by the Udzungwa Mountains in the north and west and the Mbarika Mountains and the Mahenge Highlands in the south. The valley has a subhumid tropical climate with a distinct seasonality with only one rainy season (Camberlin and Philippon 2002; Zorita and Tilya 2002). However, there are huge inter- and intra-annual and spatial variations in rainfall distribution in the region with shifts from unimodal to bimodal rainfall patterns between years (Näschen et al. 2018; Näschen et al. 2019b). Furthermore, recent decades show a drying trend in the region, which mainly affects the long rains (Yang et al. 2014), while the short rain season exhibits a shift towards wetter conditions since the $1960 \mathrm{~s}$ (Nicholson et al. 2018).

The Kilombero Valley's upland areas contribute to the braided and meandering river network of the Kilombero River (catchment size of $40,240 \mathrm{~km}^{2}$ (Näschen et al. 2018)) with several perennial and seasonal tributaries. The river's floodplain $\left(7967 \mathrm{~km}^{2}\right)$ is one of the most important fresh water wetlands in Africa (Mombo et al. 2011; Wilson et al. 2017) and since 2002 has been a designated Ramsar site with over $70 \%$ of the area protected (Nindi et al. 2014). However, there is an increasing trend of conversion of wetland and mainly grassland into arable land for rainfed rice production in the Kilombero Valley (Kangalawe and Liwenga 2005; Leemhuis et al. 2017; Näschen et al. 2019a). Additionally, deforestation or forest degradation has been increasing with growing demand for timber, fuelwood, and charcoal production (Johansson and Abdi 2020). Due to this land use and land cover change, the biophysical system is at risk; the inflow of several tributaries and the maintenance of the environmental flows are affected that determine the required quantity, quality, and timing of water flows to sustain the ecosystem and the human well-being that is connected to these ecosystems (Wilson et al. 2017; Daconto et al. 2018; Thonfeld et al. 2020).

Within this environmental setting, farmers have developed specific management strategies in response to, e.g., changes in water availability (see results section "Farmers' Perception of Human-Water Interaction"). At present, the seasonally flooded wetland of the Kilombero River is mainly used by smallholder farmers to produce rice and maize during the wet season. Currently smallholder farmers dominate agricultural production in the valley (Gebrekidan et al. 2020). Some community-based irrigation schemes do exist ( $1 \%$ of total rice area). In these schemes, a collection of farmers are members by paying a fee and by taking responsibility for its functionality, e.g., maintenance of the canals. However, besides some basic agreements, the farmers' agricultural decisions are taken independently. The irrigation system helps reduce the risk of variation in the onset of the rainy season (Näschen et al. 2019b) and supports farming year-round.

The Kilombero Valley is also highly dynamic regarding socioeconomic developments such as migration into the valley. Immigration, including a large number 

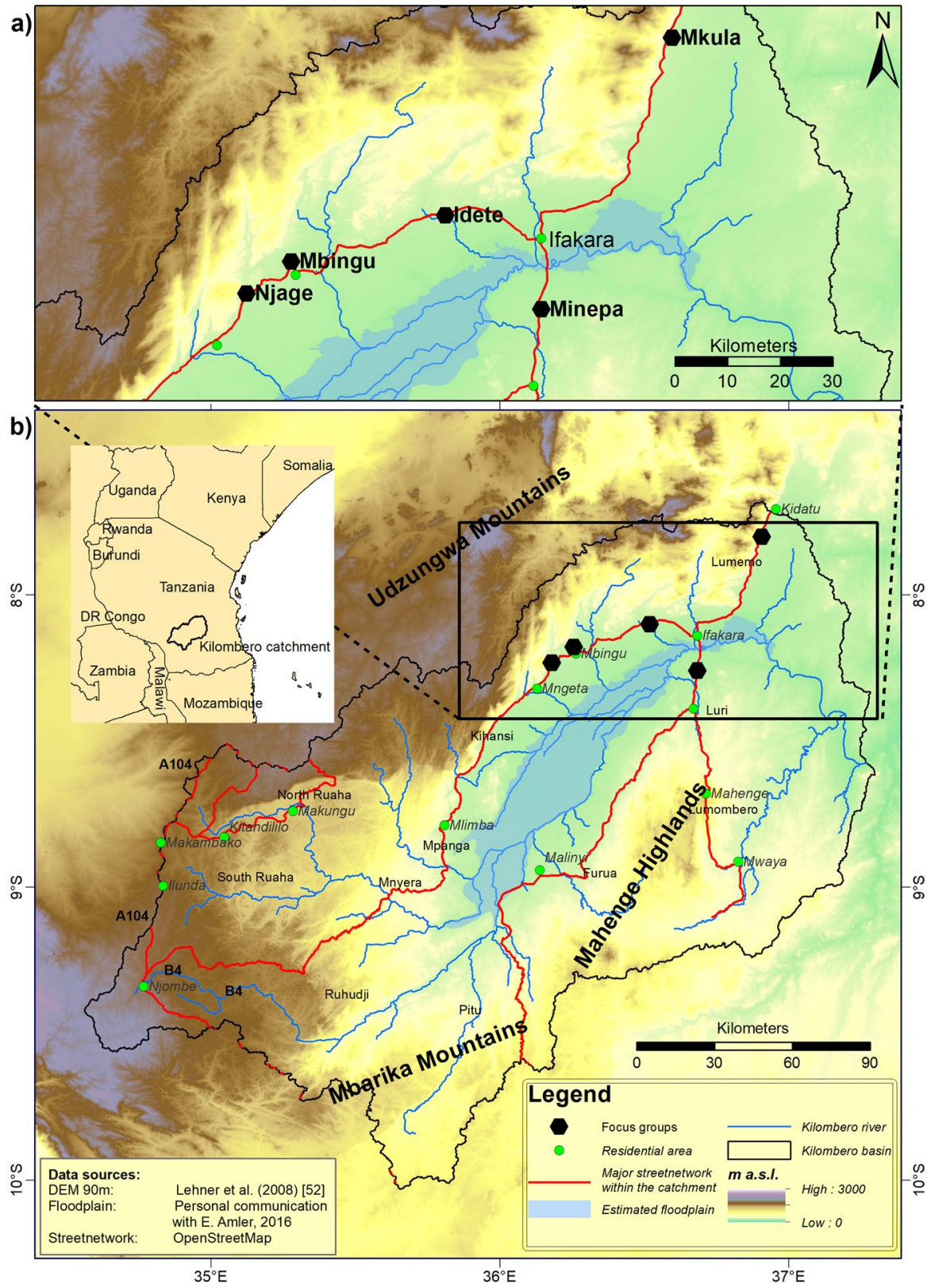

Fig. 1 a Close-up of the study sites where focus group discussions and transect walks took place, b overview of the Kilombero basin and its location within Tanzania

of pastoralists, is associated with population growth for the Kilombero area of $3.4 \%$, which exceeds the national average of 2.8\% (Msofe et al. 2019). Being part of Tanzania's Southern Agricultural Growth Corridor (SAGCOT) also comes 
with infrastructure developments such as bridge construction and expansion of paved roads (Milder et al. 2013; Tanzania 2013). Currently, SAGCOT is revising its initial plan, since the establishment of large-scale plantations did not materialize, because of national and international financial and political constraints and debates (Sulle 2020). Additionally, it is also argued that local oppositions and difficulties to gather land rights in the villages might have aggravated implementation of plans. Currently, the direction of SAGCOT with regard to out-grower schemes and the role of smallholder farmers are uncertain (Sulle 2020). Even though this national initiative has been put on hold, the vision will still resonate in farmers' minds and represents what Cleaver (2002) calls structural constraints that are anticipated by the farmers and affects their decision-making.

\section{Study Sites Characteristics}

Based on explorative field trips and literature consultation, we pre-defined criteria for study site selection. These criteria included villages (i) where irrigation or rainfed paddy rice farming is practiced and (ii) where the combination of villages covers a large variety of geographical settings (e.g., distance to mountains, forest, and floodplain) to better account for differences stemming from the physical environment affecting water availability. In total, five villages (Idete, Mbingu, Minepa, Mkula, Njage) were selected (Fig. 1). The village of Mkula lies adjacent to the protected part of the Udzungwa Mountains with its mountainous rainforest presenting one of the water towers of the Kilombero Valley (Wilson et al. 2017; Näschen et al. 2018) and the water source for Mkula's community-based irrigation scheme. The irrigation scheme is the oldest and most established in the region. It started in 1978 with building trenches and covers today an area of 254.3 ha. Njage also lies close to the Udzungwa mountains and has a community-based irrigation scheme since 1996 extending to 375 ha today although only one sixth of this area can be irrigated during the dry season. The third community-based irrigation scheme studied is located in Ulanga district across the Kilombero River in Minepa. The scheme today comprises 387 ha and was constructed in 2003 at the fringe of the Kilombero floodplain. The river Ruli, fed by the waters from the Mahenge highlands (about $50 \mathrm{~km} \mathrm{SW}$ ), provides the water resources for this scheme. There is insufficient water to irrigate the total area during the dry season. The villages of Idete and Mbingu are both villages with only rainfed farming. They are located in the lowland of the Kilombero Valley and about 5-8 km away from the forested mountains of the Udzungwa, but receive water, generated in the mountains, through their local rivers.

\section{Methodology}

In our study, we conducted focus group discussions to elicit farmers' opinions about hydrological variability and feedback mechanisms between cropping systems and water availability across time, to understand how current visions of the future manifest in space and in water-related actions. Our discussions were combined with 
participatory transect walks through the participants' fields to include structured observation of their current agricultural practices to further triangulate our data.

The fieldwork was carried out in February 2019 and conducted by Britta Höllermann, Kristian Näschen, Naswiru Tibanyendela, and Mariele Evers with support of Ernest Thomas as a second translator (Swahili - English). Hence, our research team consisted of two female and two male researchers and one male translator. The translator and one male colleague are Tanzanian, while the other three are German. In all villages, at least one researcher had already established personal contacts and presented the project and its scope beforehand.

\section{Focus Group Discussion}

By aiming at understanding the heterogeneity of farmers within their social and environmental context, focus group discussions represent an effective method of data collection (e.g., Morgan 1996). We used purposive sampling and pre-defined key characteristics of the focus group participants which included the following: (i) All participants should be rice farmers in the Kilombero valley lowland as rice represents the dominant crop there, (ii) female farmers should be included as well as (iii) different age classes to cover the diversity of farmers currently practicing rice cultivation, and lastly, (iv) the number of participants should range from 4 to 8 participants to ensure that there is a critical mass of participants to interact. Table 1 gives an overview of the characteristics of the selected farmers (gender, age class, access to irrigation). We conducted one focus group discussion in each village.

In the field, we initiated the organization of the groups by contacting the village chairs or their secretaries who then selected the participants guided by our predefined criteria. Before the discussions, we were introduced by the village leadership (chairpersons, deputies, or secretaries). After being welcomed and exchanging general information, we conducted the group discussions only with the farmers. The interviews were conducted either in the village assembly building or close by. We were able to create a trustful environment where everybody was able to speak freely. This is also due to our heterogeneous researcher group, our established local engagement, and our provision of a private room. The interaction between the

Table 1 Characteristics of focus group participants

\begin{tabular}{lllllll}
\hline Village & Number & Thereof female & $\begin{array}{l}\text { Age class } \\
25-35\end{array}$ & $\begin{array}{l}\text { Age class } \\
35-50\end{array}$ & $\begin{array}{l}\text { Age class } \\
>50\end{array}$ & Irrigation \\
\hline Idete & $7^{\text {a }}$ & 2 & 1 & 3 & 2 & No \\
Mbingu & 5 & 5 & 3 & 2 & 0 & No \\
Minepa & 5 & 1 & 2 & 3 & 0 & Yes \\
Mkula & 5 & 3 & 2 & 1 & 2 & Yes \\
Njage & 4 & 2 & 1 & 3 & 0 & Yes \\
SUM & 26 & 13 & 9 & 12 & 4 & 14 \\
\hline
\end{tabular}

${ }^{\text {a }}$ Two of the farmers had to leave the focus group discussion earlier and hence could not contribute to the results presented in Fig. 2 
farmers was very respectful. The constant translation between Swahili and English extended the course of the discussion, but was taken with patience. As the translation during the discussion was summarized compared to the transcript, we could have missed a chance to dig deeper into some aspects mentioned by the farmers, e.g., one female farmer raised the topic of women empowerment which could not be followed in more depth. However, due to the very attentive attitude of the participants and their willingness to show emotions, we are confident that the farmers gave credible responses when asked about their aspiration which heavily intrudes their personal life.

We used guiding questions to ensure comparability of the results among the five group discussions. The interview started with questions covering current crop production in order to have an easy start as the farmers are the experts and would feel confident and competent. These were followed by questions covering the hydro-climatic conditions and, if applicable, questions regarding the irrigation scheme. The second part of the discussion covered topics such as changes and impacts, rules and regulations, and visioning the future.

\section{Transect Walks}

After the focus group discussion together with the participants we visited their fields extending our exchange during a transect walk (McNall and Foster-Fishman 2007). In our case study, we followed a transect from village meeting point to fields mostly on foot which intensified the impressions of buildings and housing conditions in the village and the accessibility of the fields. Thus, we could experience the challenges of local farmers and observe their applied local technology and practices in action and in relation to the features along the transect. Additionally, the participants were able to refer to content during the focus group discussion by explaining their argument again using a physical object (e.g., effects of plant disease or pests). Thus, those transect walks allowed a deeper understanding of information gathered during previous focus group discussions. Previously mentioned management practices were observed in real time and thus contextualized and helped to triangulate the data.

\section{Analyzing Farmers' Aspirations and Decision-Making Strategies}

The analysis of the focus group discussion on farmer's aspiration and decision-making strategies is based on the recorded discussions which have been translated wordby-word from Swahili into English. The transcripts were contextualized using field notes by the authors reflecting on non-verbal communication during the discussion, such as nodding as a form of agreement. In this study, we apply thematic analysis for our focus groups (Riger and Sigurvinsdottir 2016). During this multi-step and recursive procedure, our coding covers three main themes: (1) farmers' agricultural decisions and coping mechanisms in relation to varying water availability, (2) identification of farmers' level of agency, and (3) farmers' aspirations and projected agroeconomic future of the Kilombero Valley. 
For the first theme, we collected the farmers' adopted practices and perceptions related to the seasonality of water availability. Hereby, we searched for differences and commonalities between the farmers within one village and also across the villages. This comparison allowed insights into the effect of different resource bases and the handling of these differences.

During the focus group discussions, it became clear that farmers have different levels of agency to respond to the dynamics of the social-ecological system they are part of. Westley et al. (2013) describe this adaptation to highly uncertain changes as an opportunity context which is used differently by actors. The level of purposive action and the ability to make choices are, thus, important criteria of agency (Sud 2012). Based on these criteria and the analysis of the first coding theme, we could divide our participants into farmers who are very active agents, who always try to increase their scope by taking new actions and making investments (either material or immaterial), and into farmers who are more passive and accept their restricted room for action and who rely on past practices.

At the end of the focus group discussion, the participants directly reflected on their hopes and aspirations and also projected a general development of the Kilombero Valley for the next 10 to 20 years. This latter picture describes what the farmers, based on their past experiences, realistically expect or believe will likely happen regarding the agro-economic development of the Kilombero Valley. The identification of farmers' hopes and aspirations and their judgment regarding this expected agro-economic development builds the basis for our third coding theme, where we portray the farmers' different positions in relation to each other using a positional map (Clarke et al. 2018) (see Fig. 2). This map covers the relation between two axes and their dimension: the level of aspiration and the level of expected agro-economic development. This development (the $x$-axis) was sketched on a scale from stagnating/business as usual (0) to positive $(++)$ development according to the following key aspects raised by the participants: rice price, infrastructure development, mechanization (power tiller, tractor), intensity of rice farming, irrigation, marketing, and post-processing (milling) possibilities. The ranking of these key aspects follows an ordinal scale and was derived from the participants' qualitative description of these aspects in relation to each other. Thus $(++)$ indicates very high expectation in marketing and post-processing opportunities backed by a high intensity of rice farming and mechanization, while the lower end only expects smaller increase in rice prices and less opportunities regarding infrastructure development and mechanization. In most cases, the farmers mentioned more than one of these aspects to describe a more holistic picture. However, for our visualization on the map, we positioned the farmers at the maximum of their expectations for the valley. All of the farmers individually described how they personally expect the agro-economic development to proceed, with exception of the farmers from Mbingu who provided only one expected agro-economic development based on consensus (agreement showed by nodding, clapping, supporting sounds). For the y-axis, we again positioned the aspirations of each farmer on an ordinal scale. The summary of all aspiration statements shows a range from ensuring food security (0), good housing, (good) education for their children, ensuring access to health care, starting small business, having means of transport (motorcycle to car), mechanize farming (power tiller, tractor), increasing 
farm size, becoming an entrepreneur, and starting a bigger business $(++)$. The aspiration terms were raised and ranked by the farmers using qualitative descriptors and also by commenting on especially high aspirations. For example, the details of aspiring to own a means of transport differed. While for some a motorcycle was the furthest aim, others hoped to own a car. During the discussion, it became clear that higher-level mechanization (e.g., using tractor) or post-processing harvest were things that many farmers did not dare to aspire to, so the distance between mechanization, post-processing, and agri-business is larger than between other aspirations. The final position of each farmer within the positional map indicates their highest aspired level. By sketching farmer's aspirations against their personal projection of the future development of the valley, we were able to identify the degree of discrepancy between aspirations and expected agro-economic development.

\section{Results and Discussion}

Especially in a seasonal climate, water availability is an essential and limiting factor for agricultural production. In the following, smallholder farmers' rationales and decision-making strategies on agricultural practices are presented and discussed. After introducing the experienced availability of water and the perception of farmers regarding the hydro-climatic challenges of a seasonal climate, we elaborate on how the expected agro-economic development of the valley is related to farmers' aspiration and agency. Following a discussion where we relate our findings to the broader development debate over the importance of aspirations, we conclude by highlighting the impact of the physical environment on aspirations and linked farmers' efforts.

\section{Farmers' Perceptions of Human-Water Interactions}

The focus groups highlight how the perception of seasonality is a challenge for implementation of agricultural practices, decision strategies, and shaping future development expectations. In general, the farmers perceive the seasonality of the climate and its variability as normal and have developed specific strategies to cope with this uncertainty. This is similar to findings reported in Uganda, where farmers are also used to climate variation between March and May, although there they additionally perceive it to be more variable today than in the past (Osbahr et al. 2011). In the Kilombero, both rainfed and irrigation farmers show flexibility in their cropping calendars, by following the wetting front as it moves from lower to higher parts and by choosing rice genotypes according to their phenology and physiology to adapt to different flooding heights. For example, tall rice varieties were planted in flood-prone areas while short duration varieties were grown in upland areas during the short rains. Although farmers have specific dates on which to plant, they carefully observe the weather patterns to decide on the right time to start planting in response to the variability of the onset of the rainy season. These observations include the direction of cloud formation, sound of thunder, flowering and the appearance of fresh leaves of mango trees. These indicators vary with the location 
of the villages and their proximity to the mountains. The integration, and adoption, of climate change concerns is not specific to these communities. In the west African Sahel which is historically prone to long and severe droughts, farming communities have used indigenous knowledge to mitigate and adopt strategies that enabled them to cope with climate variability (Nyong et al. 2007). On the other hand, farmers with access to irrigation schemes highlight the risk-reducing impact of irrigation towards increasing food and income security. In addition, farmers from rainfed-only villages aspire to year-round cultivation using irrigation as water is the key limiting factor for cultivation and cannot be substituted as one farmer from Mbingu states: "We get a lot of training on the improved methods of farming but since the weather is not good, there is no way of implementing these technologies." However, this is not a sentiment confined to the rainfed farmers and is also voiced by the irrigation farmers. In Njage, for example, the irrigation system is hardly effective during the dry season and most farmers are unable to cultivate under prevailing water scarcity, in particular those having their fields at the tail-end of the system.

Irrigation systems, when fully operative, provide two important opportunities. First, at the beginning of the rainy season, irrigation mitigates the high variability regarding the onset of the rains and the little dry spell during February. Second, irrigation schemes in general allow at least a second season of rice cultivation if the source provides enough water. Farmers from Mkula, living adjacent to the rainforest, are aware of the function of a healthy forest for water provision. They "are also very serious with forest protection and [they] (we) feel that this has the advantages of having rain in periods where our colleagues are facing challenges" (Farmer from Mkula). These few examples highlight how important the human-water interactions are for the Kilombero Valley. Similar findings were reported from central Tanzania, where a discussion group agreed that forests were a major contributing factor to rainfall but had lost confidence in other signs of nature (Slegers 2008). Water scarcity is a perceived constraint, but at the same time, smallholder farmers have adapted to the seasonality and also found coping mechanisms to increase agricultural output. We need this understanding of the physical environment to assess how the perception of and coping with water variability translates into and alters aspirations.

The resource base differs among the studied villages as well as the farming strategies followed. In the next section, we have a deeper look at how this affects farmer's aspirations within the expected agro-economic development of the Kilombero Valley.

\section{Farmers' Aspiration in Relation to the Expected Agro-economic Development of the Kilombero Valley}

The focus group discussion revealed how each farmer viewed the tension between their expected future of the Kilombero Valley and their own aspired future. Here the expectations describe their understanding of the likelihood of possible development, while the aspiration describes the farmers' own preferences and hopes (Bernard and Taffesse 2014). In addition, decision-making strategies perceived constraints and 
different levels of agency could be identified, providing explanations for the gap between the generally expected future and personal levels of aspiration.

Figure 2 summarizes the findings of our positional analysis where the relation between individually expected agro-economic development and the farmers' aspirations is portrayed. The unfilled circles in Fig. 2 represent those farmers who respond to expected agro-economic development by addressing potential constraints. These perceived constraints range from an imbalance between rice prices and living costs, land conflicts (land grabbing problematic, decrease of area per person due to population growth including migration and size of protected areas), limited water availability, and also lack of political power which put the expected agro-economic development at risk. While some see these constraints applying to all farmers of the valley, others point out that positive development will continue, although not all farmers will participate in this development as indicated by their different levels of aspiration.

Figure 2 suggests that the more farmers expect positive agro-economic growth for the Kilombero Valley, the more they aspire for themselves regarding well-being and benefits. Within this bigger picture, the positional map shows that there is no 'easy' clustering according to village or to an irrigation scheme because rainfed farmers also have high aspirations. Our analysis shows that farmers have different levels of agency to respond to their dynamic environment and that they have different capacities to cope with, e.g., climate variability (see previous results section). We could classify our participants into active agents (within the large black circle in Fig. 2),

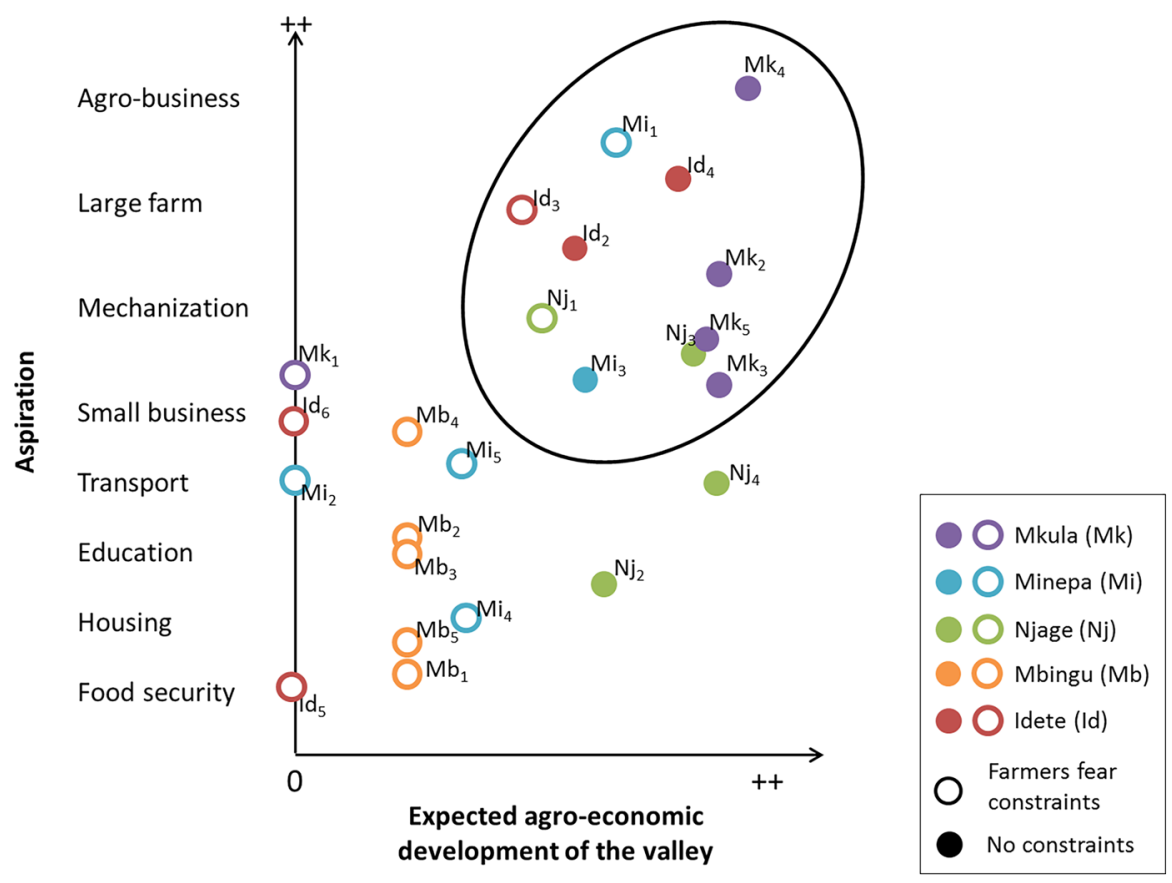

Fig. 2 Positional map of expected agro-economic development and farmers' aspiration. For further explanation, see text 
who increase their scope of action by adopting new actions and make material (e.g., power tiller) or immaterial (e.g., claim training) investments, and into more passive farmers, who rely on past practices and do not try to increase their room for action. Dorado (2005) describes the latter as routine agency which replicates past behavior and the former as strategic agency where actors actively take action to improve their current condition and close the gap between the current and the aspired condition (Rao et al. 2020). An example of the passive or routine agency comes from Mbingu where all the farmers hope for irrigation but rely on external intervention rather than their own activity ["We shall be very happy if it (irrigation) comes," statement by Mbingu farmer and adored by the group]. There is a strong link between agency and aspiration as farmers with a high level of agency are the ones who aspire the most. For active agents having a good house, good education for their children and means of transport was somehow mandatory and they hoped to benefit from the extension of mechanization by buying a power tiller or even a tractor in order to cultivate larger fields and to mobilize labor for other activities such as starting their own business. With this impetus, aspirations will reinforce themselves and decrease the gap between preferred and expected futures. Furthermore, only 3 out of those 11 active/ strategic agents perceive any constraint on their aspiration. In contrast, the opposite holds true for the more passive farmers, where 10 out of 13 are concerned about constraints potentially affecting and decreasing their aspiration level. They perceive little ability to work around those constraints. For example, in Minepa, volatile raw rice prices are perceived as a constraint by some farmers who do not see any option but to accept any development, while farmers from Idete and Mkula responded to this uncertainty by milling their rice to mitigate this price volatility and at the same time to increase their revenue.

Another major constraint raised by farmers is related to land conflicts. They fear income losses as they see the available area per person reducing although thoughts concerning arable land per person vary. Some think that the Kilombero Valley is very attractive to immigrants and that is leading to increased population growth and hence demand for agricultural land. Others argue that the efforts of the government to secure the protected areas will increase pressure on the available land. Furthermore, some think that outside-valley investors will acquire land and leave the local population landless as one farmer from Njage fears: "However, with the more people involved in farming (...) renting land will be difficult. Hence, there will be a challenge of smallholder farmers who are resource-constrained. Therefore, the future of our children is more likely to be a problem. Looking at Njage, you find that people from Dar Es Salaam have now infiltrated rice farming." The latter concerns are pointed out strongly by farmers who generally see a very positive development of the valley but have lower aspirations regarding their own well-being. The perceived constraints directly translate into a reduced personal window of aspiration. Even though this concern is also shared by farmers who have higher aspirations, they do not personally feel affected and only see the risk for some of the local farmers. In general, most rainfed farmers (8 out of 10) refer to the problem of land grabbing, while only 3 out of 14 of the irrigation farmers share this concern. One could argue here that the integration of those farmers into a community-based system and its membership policy provides more security. 
The lack of water during the dry season prevents year-round farming, so the rainfed farmers long for an irrigation scheme because they believe in a more general economic boost triggered by irrigation. According to this reasoning, one would expect generally high aspiration levels among irrigation farmers, but the picture is not so clear as Fig. 2 shows. During the focus group discussions and the transect walks in each of the three irrigated villages, it became apparent that the quality of the irrigation system, the amount of water during the dry season, the access to resources, and the applied agricultural practices differed between villages. Mkula's farmers, whose aspirations are correlated with the expected agro-economic growth, are better equipped with a well-maintained irrigation scheme and effective distribution. Even though they also have to reduce the area under cultivation during the dry season, the decrease is far smaller than in the other two schemes. The effectiveness of the irrigation scheme also relates to better access to agricultural practice trainings, as one farmer reflects: "I would also like to add that the irrigation scheme has opened doors to various organizations that train us in different disciplines. We have been taught how to grow plants that ensure good nutrition and balanced diets. We received training in gender in water management. [...] We are privileged to receive various training not in rice-growing alone but also in other areas of development." The farmers with high strategic agency successfully implemented the lessons and consequently receive further training, a positive and reinforcing effect. The village is in close proximity to the main road to Dar es Salaam and the nearby water source is also an important factor. In contrast to this privileged position, Minepa and Njage suffer from less efficient distribution of water during the dry season. While some farmers there regularly receive water, many fields have no access to water during this period and only the farmers with fields closest to the source benefit. Additionally, some farmers struggle to buy timely and sufficient inputs such as fertilizers. Especially in Minepa farmers find timely harvest and transportation from the field difficult. These brief examples show that irrigation schemes alone are not a blueprint for success or for high aspirations. Other factors such as access to material and training resources, as well as timely availability of cash and labor, also correlate with the level of aspiration. Although access to irrigation is in general supportive, it is not a guarantee of high aspiration. Conversely, no access to irrigation is not synonymous with lower aspiration levels. For example, farmers of Idete and Mbingu, currently with no access to irrigation, have developed mechanisms to cope with the seasonality of water availability that limits their agriculture practices. They make maximum use of the different field elevations and the corresponding water availability at the start of the rainy season. Recession cropping with maize, cowpeas, or pigeon peas, either for food production or for enhancing soil fertility, is common in both villages. Some farmers in Idete even grow another cycle of rice by making use of diverted river water which is then kept in the fields using bunds. In Idete, we find some very strategic farmers with high agency and willingness to invest in order to react to changes. For example, they substituted their usual cassava production with rice cultivation in 2005-2010. The initial driver of change was a pest affecting the crop, but the farmers have since discovered the relative benefits of rice cultivation (e.g., market prices), and they shifted completely to rice. This capacity to aspire, in combination with the high level of agency, directly affects their level of aspiration and 
explains why farmers in Idete generally have higher aspiration rates than farmers in Mbingu. We can conclude that understanding current farming practices and especially their heterogeneity needs explanation in the context of the interplay between perception of the physical environment, agency, and aspiration.

\section{Aspirations and Farmers' Agency}

Aspirations are generally perceived as one important factor influencing future-oriented behavior. They act as motivators to be pro-active and to aim at multi-dimensional life outcome (Bernard and Taffesse 2014). However, Appadurai (2004) notes that aspirations are not distributed evenly among the population which is reflected in our results (Fig. 2). A poverty trap may be created when low aspirations limit social mobility (Ray 2006; Dalton et al. 2016). Ray (2006) highlights the impact of the size of the aspiration gap, which is described by the difference between the current standard and the individual aspired status. Hereby, the size of the gap highly influences the amount of efforts to close this gap. In contrast to a small or very large gap, a medium gap size follows the most efforts to materialize aspirations, because, if there is only a small gap the additional benefit is estimated as too low to take action, and if the gap is large, people feel overwhelmed preventing any action. In our study, farmers' aspiration increases with their increased expected regional agroeconomic growth. However, we could also identify a deviation from this more general result, where some farmers doubt to benefit from the positive expected agroeconomic development of the valley's future (see, e.g., farmers $\mathrm{Nj} 2$ and $\mathrm{Nj} 4$, Fig. 2). This decoupled perception of personal benefit-participation and regional development reveals another type of aspiration gap, with high consequences regarding the willingness to invest in the future as not only higher aspirations translate into higher investments (Kosec and Mo 2017), but also the perceived size of the gap. This willingness is reflected in our farmers' aspirations and highlights the underlying livelihood strategy. Dorward et al. (2009) distinguish three types: "hang in", "stepping up", or "stepping out". The identified strong link between the perception of the physical environment, the agency of a farmer, and her/his level of aspiration made it clear that the more farmers own and play out their agency the more they feel competent to face and respond to challenges and changes in the physical environment and the more they dare to aspire for themselves, and vice versa. This has a reinforcing effect which directly translates into adoption of agricultural practices that will close the gap between the current and the aspired condition (Rao et al. 2020). On the other hand, more passive agents feel less secure and, even though they might expect positive agro-economic development of the valley, their lower level of aspiration shows that their confidence that they will equally profit from this development is much lower. Passive agents are mostly farmers with limited access to resources such as inputs, labor, cash, and training. They are less certain regarding the likely revenue from a season and feel strongly affected by external conditions, so reducing their room for action which is described as the poverty trap or vicious circle (Appadurai 2004; Ray 2006; Dalton et al. 2016). Hence, the farmers with low levels of aspiration and who focus on food security are those who "hang in", while the farmers with 
a high level of agency and hence higher aspirations belong to the socially mobile groups of "stepping up" or "stepping out". Farmers who invest in mechanization to set labor free for other economic activities even belong to a hybrid type "stepping out while staying put" (Verkaart et al. 2018). Mausch et al. (2018) and Verkaart et al. (2018) propose that focusing on the "stepping up" farmers for dissemination of, e.g., agricultural technologies will fast-track development. Access to trainings is one example supporting this viewpoint. Farmers from Mkula receive considerably more trainings than farmers from the other villages and they are more effective in implementing and benefiting from the learning outcomes of those trainings. This bears the risk that development efforts are missing in other places, while the farmers currently benefitting may have reached a stage where this support reaches saturation. Farmers orient within their relevant peers and their aspiration window, potentially limiting aspirations below their own capabilities (Ray 2006), but the question remains if, and how, those aspirations are malleable (Kremer et al. 2019). Bernard et al. (2014), for example, showed a positive effect on people's aspirations when they were exposed to documentaries about people with similar status who had achieved something. We see a similar effect here when farmers refer to neighboring villages. For example, in Idete, the farmer with the highest aspiration states: "In 10 years to come, I think there will be an increase in development (...) people are benefiting from rice production for example when you look at Chita [name of nearby village] there is a lot of development." In contrast, for farmers of Mbingu such comparisons play a minor role regarding their aspirations. For example, the access to training in good agricultural practices such as in-line planting with seedlings instead of broadcasting seeds is appreciated, but not subsequently implemented. We could observe this during the transect walks. The farmers argue that there is a trade-off between the labor input and the revenue. These findings highlight that aspirations can be malleable by, e.g., external input although not in every case. In Mbingu's case, the improved techniques are viewed as saving seed rather than increasing income; hence, they are only used in times of seed shortages. This is a good example of farmers who need to balance multiple strands of income generation under limited resources (Mausch et al. 2018). We can conclude that the combination of access to assets such as inputs and training builds the basis for active agency and increases confidence about increasing the personal room for action and also the capability to cope with environmental changes. However, this personal room for action is constantly challenged by seasonality and hydro-climatic variability. A lack of access to water or irrigation may put harvests at risk or even does not allow cropping at all. This uncertainty is perceived twofold. The variability of the onset of the rainy season is part of their lives, but at the same time farmers are aware of the importance of protecting their water source. This is not only true for Mkula with their irrigation scheme and proximity to the forest, but also for rainfed farmers in Mbingu who preserve higher elevated patches of secondary forest to ensure soil moisture after the rainy season. We regard these protection measures as non-material investments in "stepping up". The same is true for other agriculturaldecisions intended to cope with seasonality or hydro-climatic variability such as building bunds to keep the water in fields, by using residual soil moisture for a second crop and choosing location-specific rice genotypes adapted to different flooding heights. Hence, we see strong links between the level of aspiration, the 
current socioeconomic situation, and the coping capacity regarding challenges and constraints due to hydro-climatic variabilities expressed via agricultural practices.

\section{Concluding Remarks}

Our research highlights how farmers' actions shape and respond to the highly dynamic and uncertain environment they are faced with. Furthermore, we identify a close link between aspirations and expected agro-economic development which is also driven by the farmers' level of agency. We find that the heterogeneity of farmers' agency and hence their ability to cope with change is not only based on their socioeconomic status but also on individual or group-based environmental perceptions and coping capacities. Adding the impacts of, and responses to, the physical environment to the duality of the relationship between agency and aspiration helps to understand farmers' decision-making and their agricultural practices. These practices again shape the farmers' window of aspiration and the perceived room for action. Therefore, we argue that, besides the influence of economic relations on aspirations (Kremer et al. 2019), the influence of environmental factors and the interaction with the physical environment should also be taken into account to understand farmers' decision-making strategies and their future-oriented efforts. This adds another important dimension to understand the unevenly distributed levels of agency and aspiration. We thus highly recommend that further studies in this field should acknowledge human-environment interactions and, in an agricultural context, particularly the human-water dynamics.

Acknowledgements We are grateful for our focus group participants who supported our study by sharing their farming expertise and experience during lively discussions and transect walks. We appreciate their hospitality and the time they took to engage with us despite their busy farming schedule. We gratefully acknowledge Thomas Ernest who supported with translation during the focus group discussions. We would also like to thank three anonymous reviewers and the editor for their critical and supportive comments.

Funding This study was supported through funding from the German Research Foundation (DFG) under the CRC/Transregio 228: Future Rural Africa: Future-making and social-ecological transformation (Project Number: 328966760). Open Access funding enabled and organized by Projekt DEAL.

\section{Declarations}

Conflict of interest The authors declare that they have no conflicts of interest.

Open Access This article is licensed under a Creative Commons Attribution 4.0 International License, which permits use, sharing, adaptation, distribution and reproduction in any medium or format, as long as you give appropriate credit to the original author(s) and the source, provide a link to the Creative Commons licence, and indicate if changes were made. The images or other third party material in this article are included in the article's Creative Commons licence, unless indicated otherwise in a credit line to the material. If material is not included in the article's Creative Commons licence and your intended use is not permitted by statutory regulation or exceeds the permitted use, you will need to obtain permission directly from the copyright holder. To view a copy of this licence, visit http://creativecommons.org/licen ses/by/4.0/. 


\section{References}

Appadurai, A. 2004. The capacity to aspire: Culture and the terms of recognition. In Culture and public action, ed. Y. Rao and M. Walton, 59-84. Stanford, CA: Stanford University Press.

Bernard, T., S. Dercon, K. Orkin, and A. Taffesse. 2014. The future in mind: Aspirations and forwardlooking behaviour in rural Ethiopia. London: Centre for Economic Policy Research London.

Bernard, T., and A. Taffesse. 2014. Aspirations: An approach to measurement with validation using ethiopian data. Journal of African Economies 23 (2): 189-224.

Camberlin, P., and N. Philippon. 2002. The East African March-May rainy Season: Associated atmospheric dynamics and predictability over the 1968-97 period. Journal of Climate 15: 1002-1019.

Clarke, A.E., C. Friese, and R. Washburn. 2018. Situational analysis: Grounded theory after the interpretive turn. Los Angeles; London; New Delhi; Singapore; Washington DC: Sage.

Cleaver, F. 2002. Reinventing institutions: Bricolage and the social embeddedness of natural resource management. The European Journal of Development Research 14 (2): 11-30.

Daconto, G., I. Games, K. Lukumbuzya and F. Raijmakers. (2018). Integrated Management Plan for the Kilombero Valley Ramsar Site. Integrated Management.

Dalton, P.S., S. Ghosal, and A. Mani. 2016. Poverty and aspirations failure. The Economic Journal 126 (590): 165-188.

Dorado, S. 2005. Institutional entrepreneurship, partaking, and convening. Organization Studies 26 (3): 385-414.

Dorward, A., S. Anderson, Y.N. Bernal, E.S. Vera, J. Rushton, J. Pattison, and R. Paz. 2009. Hanging in, stepping up and stepping out: livelihood aspirations and strategies of the poor. Development in Practice 19 (2): 240-247.

Finlayson, C.M., G.R. Milton, R.C. Prentice, and N.C. Davidson. 2018. The Wetland Book: II: Distribution, description, and conservation. New York: Springer.

Gabiri, G., S. Burghof, B. Diekkrüger, C. Leemhuis, S. Steinbach, and K. Näschen. 2018. Modeling spatial soil water dynamics in a Tropical Floodplain, East Africa. Water 10 (2): 191.

Gebrekidan, B.H., T. Heckelei, and S. Rasch. 2020. Characterizing farmers and farming system in Kilombero Valley Floodplain, Tanzania. Sustainability 12 (17): 7114.

Huijsmans, R., N. Ansell, and P. Froerer. 2020. Introduction: Development, young people, and the social production of aspirations. The European Journal of Development Research 1: 1-15.

Johansson, E.L., and A.M. Abdi. 2020. Mapping and quantifying perceptions of environmental change in Kilombero Valley, Tanzanio. Ambio 49 (2): 557-568.

Kangalawe, R.Y.M., and E.T. Liwenga. 2005. Livelihoods in the wetlands of Kilombero Valley in Tanzania: Opportunities and challenges to integrated water resource management. Physics and Chemistry of the Earth, Parts A/B/C 30: 968-975.

Kosec, K., and C.H. Mo. 2017. Aspirations and the role of social protection: Evidence from a natural disaster in rural Pakistan. World Development 97: 49-66.

Kremer, M., G. Rao and F. Schilbach. (2019). Behavioral development economics. Handbook of behavioral economics: Applications and foundations: 345-458.

Kwesiga, J., K. Grotelüschen, D. Neuhoff, K. Senthilkumar, T.F. Döring, and M. Becker. 2019. Site and management effects on grain yield and yield variability of rainfed lowland rice in the Kilombero Floodplain of Tanzania. Agronomy 9 (10): 632.

Kwesiga, J., K. Grotelüschen, K. Senthilkumar, D. Neuhoff, T.F. Döring, and M. Becker. 2020. Rice yield gaps in smallholder systems of the Kilombero Floodplain in Tanzania. Agronomy 10 (8): 1135.

La Ferrara, E. 2019. Presidential address: Aspirations, social norms, and development. Journal of the European Economic Association 17 (6): 1687-1722.

Leemhuis, C., E. Amler, B. Diekkrüger, G. Gabiri, and K. Näschen. 2016. East African wetland-catchment data base for sustainable wetland management. Proceedings of the International Association of Hydrological Sciences 374: 123.

Leemhuis, C., F. Thonfeld, K. Näschen, S. Steinbach, J. Muro, A. Strauch, A. López, G. Daconto, I. Games, and B. Diekkrüger. 2017. Sustainability in the food-water-ecosystem nexus: The role of land use and land cover change for water resources and ecosystems in the Kilombero Wetland, Tanzania. Sustainability (Switzerland) 9: 1513.

Mausch, K., D. Harris, E. Heather, E. Jones, J. Yim, and M. Hauser. 2018. Households' aspirations for rural development through agriculture. Outlook on Agriculture 47 (2): 108-115. 
McNall, M., and P.G. Foster-Fishman. 2007. Methods of rapid evaluation, assessment, and appraisal. American Journal of Evaluation 28 (2): 151-168.

Milder, J.C., A.K. Hart, and L.E. Buck. 2013. Applying an agriculture green growth approach in the SAGCOT clusters: Challenges and opportunities in Kilombero. Dar es Salaam: Ihemi and Mbarali.

Mombo, F., S. Speelman, G.V. Huylenbroeck, J. Hella, and S. Moe. 2011. Ratification of the Ramsar convention and sustainable wetlands management: Situation analysis of the Kilombero Valley wetlands in Tanzania. Journal of Agricultural Extension and Rural Development 3 (9): 153-164.

Morgan, D. 1996. Focus groups. Annual Review of Sociology 22: 129-152.

Msofe, N.K., L. Sheng, and J. Lyimo. 2019. Land use change trends and their driving forces in the Kilombero Valley Floodplain, Southeastern Tanzania. Sustainability (Switzerland) 11: 1-25.

Näschen, K., B. Diekkrüger, M. Evers, B. Höllermann, S. Steinbach, and F. Thonfeld. 2019. The impact of land use/land cover change (LULCC) on water resources in a tropical catchment in Tanzania under different Climate Change Scenarios. Sustainability 11 (24): 7083.

Näschen, K., B. Diekkrüger, C. Leemhuis, L.S. Seregina, and R. v. d. Linden, . 2019. Impact of climate change on water resources in the Kilombero catchment in Tanzania. Water 11: 859.

Näschen, K., B. Diekkrüger, C. Leemhuis, S. Steinbach, L. Seregina, F. Thonfeld, and R. Linden. 2018. Hydrological modeling in data-scarce catchments: The Kilombero Floodplain in Tanzania. Water 10: 599 .

Nicholson, S.E., C. Funk, and A.H. Fink. 2018. Rainfall over the African continent from the 19th through the 21st century. Global and Planetary Change 165: 114-127.

Nindi, S.J., H. Maliti, S. Bakari, H. Kija, and M. Machoke. 2014. Conflicts over land and water resources in the Kilombero Valley Floodplain, Tanzania. African Study Monographs. Supplementary Issue 50: $173-190$.

Nyong, A., F. Adesina, and B. Osman Elasha. 2007. The value of indigenous knowledge in climate change mitigation and adaptation strategies in the African Sahel. Mitigation and Adaptation Strategies for Global Change 12 (5): 787-797.

Osbahr, H., P. Dorward, R. Stern, and S. Cooper. 2011. Supporting agricultural innovation in Uganda to respond to climate risk: Linking climate change and variability with farmer perceptions. Experimental Agriculture 47 (2): 293-316.

Rao, N., C. Singh, D. Solomon, L. Camfield, R. Sidiki, M. Angula, P. Poonacha, A. Sidibé, and E.T. Lawson. 2020. Managing risk, changing aspirations and household dynamics: Implications for wellbeing and adaptation in semi-arid Africa and India. World Development 125: 104667.

Ray, D. 2006. Aspirations, poverty, and economic change: Understanding poverty, 409-421. Oxford: Oxford University Press.

Riger, S., and R. Sigurvinsdottir. 2016. Thematic analysis. In Handbook of methodological approaches to community-based research: Qualitative, quantitative, and mixed methods, ed. L.A. Jason and D.S. Glenwick, 33-41. Oxford: Oxford University Press.

Slegers, M.F.W. 2008. "If only it would rain": Farmers' perceptions of rainfall and drought in semi-arid central Tanzania. Journal of Arid Environments 72 (11): 2106-2123.

Sud, N. 2012. Local agency and structural continuity: Views from an SHG-based microcredit scheme in Western India. The European Journal of Development Research 25 (2): 271-287.

Sulle, E. 2020. Bureaucrats, investors and smallholders: Contesting land rights and agro-commercialisation in the Southern agricultural growth corridor of Tanzania. Journal of Eastern African Studies 14 (2): 332-353.

Tanzania, Government of (2013) Southern Agricultural Growth Corridor of Tanzania (SAGCOT): Environmental and Social Management Framework (ESMF). Dar es Salaam.

Thonfeld, F., S. Steinbach, J. Muro, K. Hentze, I. Games, K. Näschen, and P.F. Kauzeni. 2020. The impact of anthropogenic land use change on the protected areas of the Kilombero catchment, Tanzania. ISPRS Journal of Photogrammetry and Remote Sensing 168: 41-55.

Verkaart, S., K. Mausch, and D. Harris. 2018. Who are those people we call farmers? Rural Kenyan aspirations and realities. Development in Practice 28 (4): 468-479.

Westley, F.R., O. Tjornbo, L. Schultz, P. Olsson, C. Folke, B. Crona, and Ö. Bodin. 2013. A theory of transformative agency in linked social-ecological systems. Ecology and Society 18 (3): 27.

Wilson, E., R. McInnes, D.P. Mbaga, and P. Ouedaogo. 2017. Ramsar advisory mission report: United Republic of Tanzania. Gland, Switzerland: Kilombero Valley.

Yang, W., R. Seager, M.A. Cane, and B. Lyon. 2014. The East African long rains in observations and models. Journal of Climate 27 (19): 7185-7202. 
Zorita, E., and F.F. Tilya. 2002. Rainfall variability in Northern Tanzania in the March-May season (long rains) and its links to large-scale climate forcing. Climate Research 20: 31-40.

Publisher's Note Springer Nature remains neutral with regard to jurisdictional claims in published maps and institutional affiliations.

\section{Authors and Affiliations}

\section{Britta Höllermann ${ }^{1}$ (D) Kristian Näschen ${ }^{1}$ (D) Naswiru Tibanyendela ${ }^{2,3}$. Julius Kwesiga ${ }^{2} \cdot$ Mariele Evers $^{1}$}

Kristian Näschen

knaesche@uni-bonn.de

Naswiru Tibanyendela

tibanyendela@sua.ac.tz

Julius Kwesiga

kwesigajulius@yahoo.com

Mariele Evers

mariele.evers@uni-bonn.de

1 Department of Geography, University of Bonn, Meckenheimer Allee 166, 53115 Bonn, Germany

2 INRES, University of Bonn, Karlrobert-Kreiten-Straße 13, 53115 Bonn, Germany

3 Department of Crop Science and Horticulture, Sokoine University of Agriculture, P.O. Box 3005, Morogoro, Tanzania 